\title{
Strategies for the incorporation of SMES to digital markets
}

\section{Estrategias para la incorporación de las SMES a mercados digitales}

\author{
ÁLVAREZ-GARCÍA， Mónica†*， GUERRERO-IBARRA Carlos and LARIOS-CALVA, \\ Margarita
}

Universidad Tecnológica de Nezahualcóyotl

ID $1^{\text {st }}$ Author: Mónica, Álvarez-García / ORC ID: 0000-0003-3393-1277, Reasearcher ID: B-8810-2019, arXiv ID Author: TNNNZH-KUCB98

ID $1^{\text {st }}$ Coauthor: Carlos, Guerrero-Ibarra / ORC ID: 0000-0003-0958-7912, Reasearcher ID: B-8810- 2019

ID $2^{\text {nd }}$ Coauthor: Margarita, Larios-Calva / ORC ID: 0000-0002-2356-7419, arXiv ID Author: MARGARITA.LARIOSCA, CVU CONACYT ID: 1000061

DOI: $10.35429 / J M M E .2019 .5 .3 .26 .33$

Received August 25, 2019; Accepted December 14, 2019

\begin{abstract}
This document is the result of the analysis of the situation of micro and small enterprises (SMEs) in Mexico, a documentary review and a quantitative, descriptive investigation was made showing some of the characteristics of the SMEs as economic units and the use of the WEB and social networks for the sale and commercialization of their products or services, a proposal is developed that could support their permanence in the market, as well as allowing them to be more competitive by incorporating new markets with marketing means supported by innovative technologies and digital marketing practices (ecommerce), such as the development of its WEB page, use of social networks and Marketplaces platforms, as well as CRM (Consumer Relation Ship Management).
\end{abstract}

SMES, Digital, Markets

\begin{abstract}
Resumen
El presente documento es el resultado del análisis de la situación de las micros y pequeñas empresas (SMEs) en México, se realizó una revisión documental y una investigación cuantitativa, descriptiva donde se muestran algunas de las características de las SMEs como unidades económicas y el uso de la WEB y redes sociales para la venta y comercialización de sus productos o servicios, se desarrolla una propuesta que podrían apoyar a su permanencia en el mercado, además de permitirles ser más competitivas al incorporar nuevos mercados con medios de comercialización apoyados por innovadoras tecnologías y prácticas mercadológicas digitales (e-commerce), como el desarrollo de su página WEB, uso de redes sociales y plataformas de Marketplaces, además del CRM (Consumer Relation Ship Management).
\end{abstract}

SMES, Mercados, Digitales

Citation: ÁLVAREZ-GARCÍA, Mónica, GUERRERO-IBARRA Carlos and LARIOS-CALVA, Margarita. Strategies for the incorporation of SMES to digital markets. RINOE Journal-Macroeconomics and monetary economy. 2019. 3-5: 26-33.

\footnotetext{
* Correspondence to Author (email: esmeralda.aguilar@itssmt.edu.mx)

$\dagger$ Researcher contributing first author.
} 


\section{Introduction}

The following lines present the results of an investigation into the situation in which SMEs are currently, within a changing market in the country, some statistics on the behavior of electronic commerce, social networks and a Proposal (e-commerce) of how SMEs could use these technologies to expand their market and increase their sales.

SMEs are very vulnerable and being part of a changing market, has caused their average life in it to be 7 years; This coupled with their limited resources, lack of vision, quality and clarity in their value chain, prevents them from having the growth they would like.

The disappearance of the SMEs due to lack of competitiveness, is a problem that afflicts the national economy, because these are the ones that generate $82 \%$ of employment in our country. When disappearing, important and numerous sources of employment are lost. Technological tools are proposed, which can be incorporated, to generate new marketing practices, which the current user is requiring.

SMEs must understand that the digital era has arrived and that customers move in that area. The traditional user (customer, buyer) has mutated. Now it has become much more demanding and requires prompt and accurate answers. SMEs must take on new consumer characteristics and reorient their marketing processes, both in advertising, sales and customer service. Traditional advertising has gone to second term, currently the common user, is bombarded by media such as social networks and video channels.

Sales have changed to such an extent that the current consumer before acquiring a product or service, researches the companies that offer it online, makes an evaluation and decides; You no longer have the need to move to a physical store to make the purchase, just press a couple of keys to purchase the required product or service. In the same way, as it uses the network to investigate the best seller or supplier, it also requires attention and prompt responses, which is an important weakness for SMEs, which most of their efforts are dedicated to the production process and distribution, even when the current user requires high quality customer service.
To achieve total satisfaction of the new consumer or user, SMEs must incorporate new marketing practices and improve their customer service, for this there are computer tools in the market that will allow them to maintain and grow, in addition to reaching a higher level of competitiveness.

\section{Method}

To carry out this project, a documentary investigation was first made and on the Internet, through various sources, a descriptive quantitative investigation was subsequently carried out, where the problems faced by SMEs are analyzed; The selected sample was 120 SMEs from a database of 900 companies (study universe) with the following characteristics: shops from 0 to 30 , services from 0 to 50 and industries from 0 to 100 employees, located in Mexico City and the Metropolitan Area, the database was provided by the Linking Area of the Technological University of Nezahualcóyotl, where students make their stays.

To calculate the sample, the normal distribution curve formula for finite populations was used, the standard error of $+-9 \%, 95 \%$ confidence interval and the probability values in favor and against 50\% were used.

A structured questionnaire or form with 10 closed questions was designed, it was validated in advance to avoid errors in the reliability of the data obtained. The information was collected through the Google SurveyMonkey platform with the owners, administrators or managers of the companies, this tool is easy to use and free up to 10 questions of the questionnaire. It has great advantages, among them; It allows saving time and expedites the submission of the form via email to the interviewee; At the same time it allows visualizing the responses received directly on a platform where the data is already captured and plotted.

To select the sample, non-probabilistic sampling by trial was used where the companies were selected for a natural randomness, given that the form was sent to the 900 companies and the self-selection was given by the availability and contribution provided by the entrepreneurs to answer and send the questionnaire 
Likewise, the descriptive analysis was made in which the conditions and use of technologies by the SMEs are evaluated in order to determine strategies according to their needs. The results were provided by the database obtained through Google's SurveyMonkey, subsequently, the information was plotted and interpreted. For the purposes of this investigation, SMEs are considered, those companies that have up to 30 employees in the case of shops and 50 in services. (See table 1)

\begin{tabular}{|c|c|c|c|}
\hline \multicolumn{4}{|c|}{$\begin{array}{l}\text { Estratificación de empresas publicada en el Diario Oficial de la Federación } \\
30 \text { de diciembre de } 2002\end{array}$} \\
\hline \multirow{3}{*}{ Tamaio } & \multicolumn{3}{|c|}{ Sector } \\
\hline & \multicolumn{3}{|c|}{ Clasificación seguin el número do emplaados } \\
\hline & Industria & Comercio & Senicios \\
\hline Nivo & de 0 a 10 & de 0 \& 10 & de 0 a 10 \\
\hline Pequeria & de 11 a 50 & de 11 a 30 & de 11 a 50 \\
\hline Nediana & de 51 \& 250 & de 31 a 100 & de 51 \& 100 \\
\hline
\end{tabular}

Table 1 Classification of SMEs by turnover and number of employees

\section{Reference Framework}

In Mexico there are 4 '048,543 companies (INEGI 2015), of which 3' 952, 422 are micro and 79,367 are small, indicating that both make up $99 \%$ of total companies, while only $1 \%$ corresponds to medium And big companies. The data is of the utmost importance because according to a study carried out by specialists from the Accounting School of the National Autonomous University of Mexico (2017 Conference), according to which nine out of ten SMEs small and medium sized companies in Mexico are seen forced to close the doors during the first five years of its existence, the situation reveals an important problem for the Mexican economy.

It is imperative not to forget that SMEs are responsible for providing work for $10,225,939$ workers. But even more important for this study is to recognize that microenterprises support the employment of 8 ' 675,103 workers, that is, they absorb $82 \%$ of the country's workforce, without considering large companies.

\section{Personnel Employed by Type of Company}

$8 \%$

$10 \%$

Micro
Small Medium

$82 \%$

Graphic 1 Personnel employed Source: INEGI

Likewise, INEGI (2015) pointed out that the last update of the Directory of Economic Units revealed that from 2010 to 2015, one million six hundred and thirty thousand companies closed for various reasons, while a total of two million two hundred and twenty five emerged in this same period.

Likewise, INEGI (2015) pointed out that the last update of the Directory of Economic Units revealed that from 2010 to 2015, one million six hundred and thirty thousand companies closed for various reasons, while a total of two million two hundred and twenty five emerged in this same period. INEGI also highlights that the average life expectancy for a company in our country amounts to 7.7 years, alarming data that researchers should use to find strategies or alternatives that allow SMEs greater permanence and growth in the market.

For a company to implement digital business strategies, it must start from the application of E-commerce. Cisneros considers that it is that economic activity based on the offer of products or services, either for the purchase or sale through digital media such as the internet (Cisneros E. D., 2017).

The actors involved in e-commerce are: buyer, company, company employees and the administrator, the fusion of the different activities carried out by each of them leads to the success of electronic commerce. Navárez cites the e-commerce concept of the Mexican Internet Association (AMIPCI) that defines it as the "Exchange of goods and services carried out through information and communications technologies, usually with support of standardized platforms and protocols" (Navárez J., 2014). 
There are different e-commerce models, (Cisneros E. D., 2017). Classified in 5

1. Business-to-business (B2B) participants are companies, which end up doing big business.

2. Business-to-consumer (B2C), is the most conventional, ensures a more immediate influx of customers and allows the relationship to be more direct with the producer.

3. Consumer-to (C2B), this model is aimed at Internet users end up offering something to organizations.

4. Mobile commerce (m-commerce) transactions and e-commerce activities conducted in a wireless environment (mobile banking).

5. E-government, this model is currently used mostly to make the services that the state provides to citizens more accessible.

Cisneros also mentions that the main advantages of e-commerce lie in access to global markets, the possibility of attracting customers online and offline, low development and implementation costs and a more efficient and constant update of the organization's product catalog.

\section{Results}

This section presents the results:

As can be seen in graph 2, more than half of this type of companies in Mexico City and the Metropolitan Area are trade, while 3 out of 10 are dedicated to services.

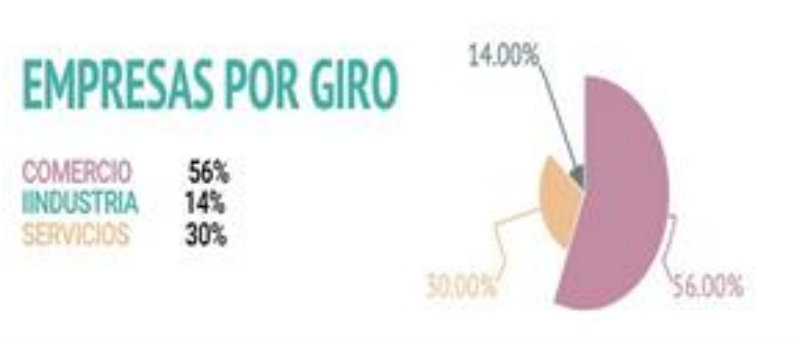

Graphic 2 Type of company

Source: own elaboration
In relation to the question about "Possession of a WEB page to promote your company, your products or services", $(68 \%)$ of the SMEs responded not to have it, some expressed that it represents an expense that they cannot do and not They have experience in the use of these technologies. (See graphic 3).

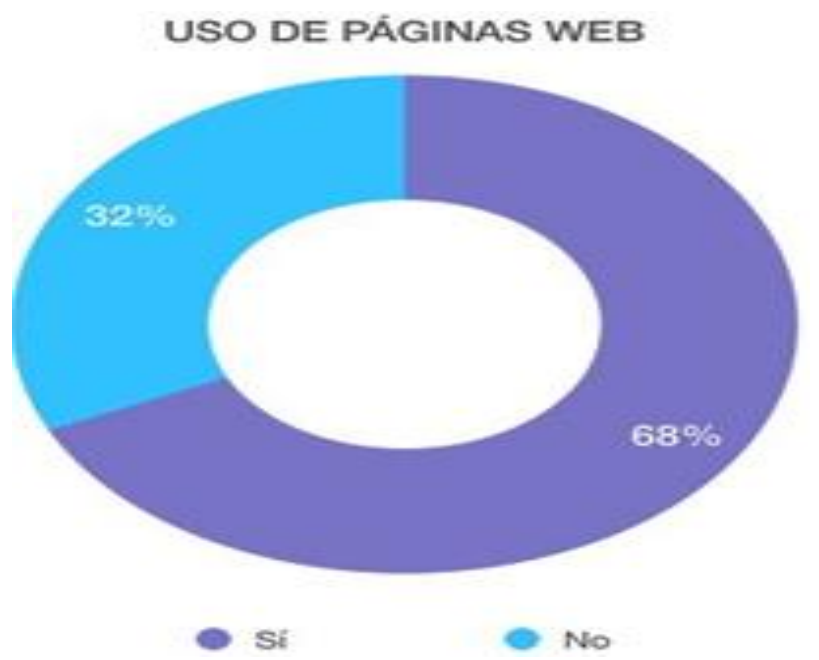

Graphic 3 WEB page

Source: own elaboration

On the questioning of the use of social networks (Graphic 4), an unexpected response was obtained, given that 7 out of 10 companies of this type already have a social network. This indicates that companies have found mobile telephony as a means of communication and use it to be in contact with their customers or to publicize their products or services. In this way it can be explained that many of these companies have formed a social network to keep their possible markets informed.

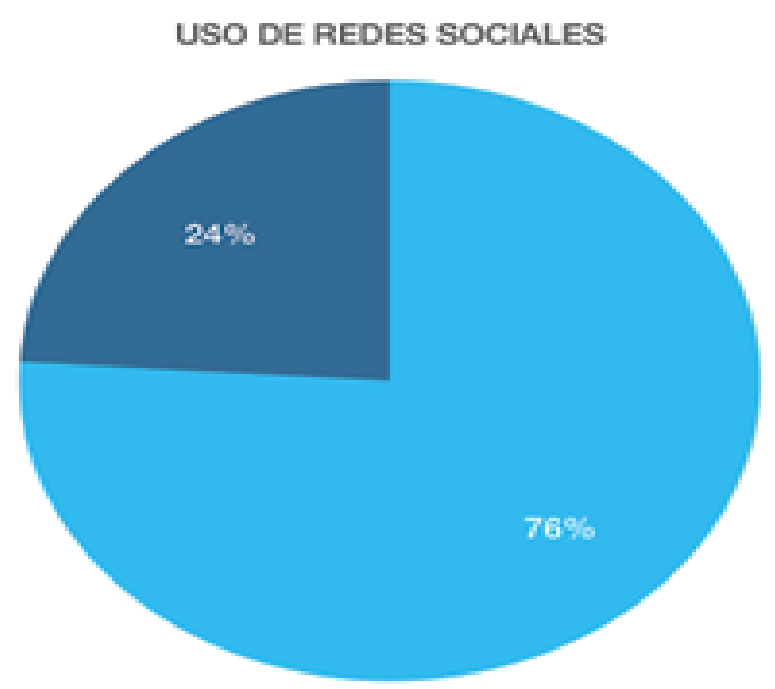

Graphic 4 Social networks

Source: own elaboration 
Graphic 5 shows that the social network most used by SMEs is Facebook, since it is the most visited platform by netizens, more versatile and easy to use, but above all they do not have to make any expense or payment to promote The company, products or services and allows them to be in constant communication with their customers. Although there is reference that few of these companies do not spend much time to follow up and even less, they have a network administrator.

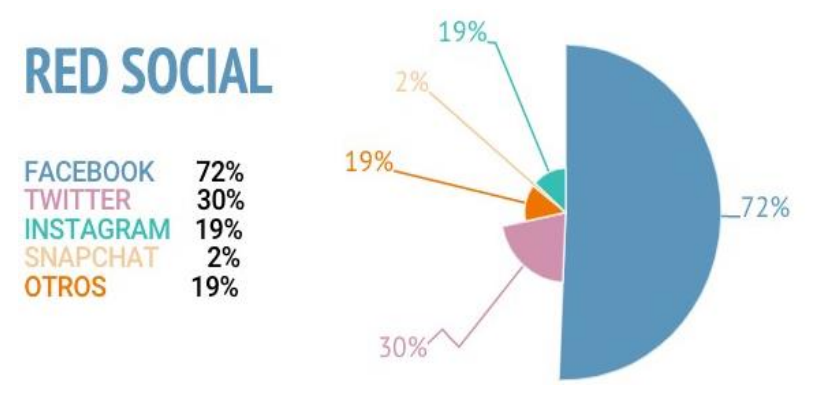

Graphic 5 Social networks used

Source: own elaboration

To understand the importance of social networks, it is convenient to comment that the Morning Consult Company conducted an investigation on the use of Facebook in companies. The data reveals that the platform is helping SMEs in Mexico, as the following graph shows, more than $65 \%$ of companies have benefited from the use of Facebook in increasing their business and sales, and it has also allowed them to generate sources of employment. In the same way in the graph it can be seen that the SMEs believe that the platform has helped them reach more customers and even in other states or countries.

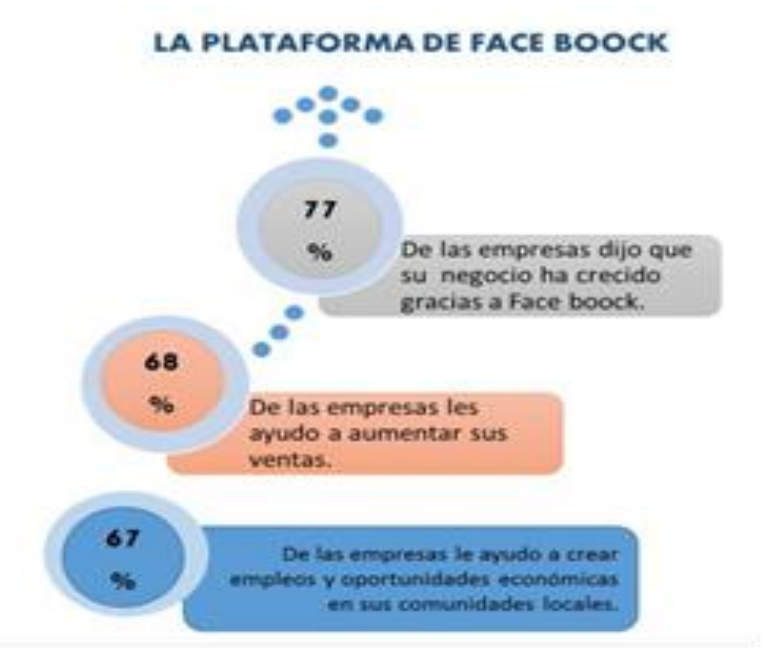

Graphic 6 The Facebook Platform, own elaboration Source: SMEs in Mexico accelerate their growth with Facebook
Graphic 7 analyzes the impact that the social network Facebook has generated in the surveyed SMEs. $78 \%$ affirm that the platform helps them reach customers that are outside their local market and that they could not access, without the help of social networks. $77 \%$ consider that the platform allows them to sell their products or services in other cities, states or countries.

\section{FACEB $00 \mathrm{~K}$}

\begin{tabular}{|l|l|}
\hline $78 \%$ & $\begin{array}{l}\text { De las PyMEs afirman que la } \\
\text { plataforma les ayuda a alcanzar } \\
\text { clientes que de otro modo serian } \\
\text { dificiles de conseguir. }\end{array}$ \\
\hline $\mathbf{7 7 \%}$ & $\begin{array}{l}\text { De las PyMEs considera que la } \\
\text { plataforma les permite vender sus } \\
\text { productos o servicios en otras } \\
\text { ciudades, estados o países. }\end{array}$ \\
\hline
\end{tabular}

Graphic 7 Facebook, own elaboration

Source: SMEs in Mexico accelerate their growth with Facebook

\section{Proposal}

After the analysis carried out, it is suggested that the SMEs should take different strategies that allow them to remain present in the markets (physical and digital), for which Michel Porter's proposal is taken up, which is broken down and shown below:

First, the SMEs must know or establish in detail their value chain, which according to Michel Porter, is an internal analysis of the company, through its disaggregation into the main value generating activities, as shown in the following figure.

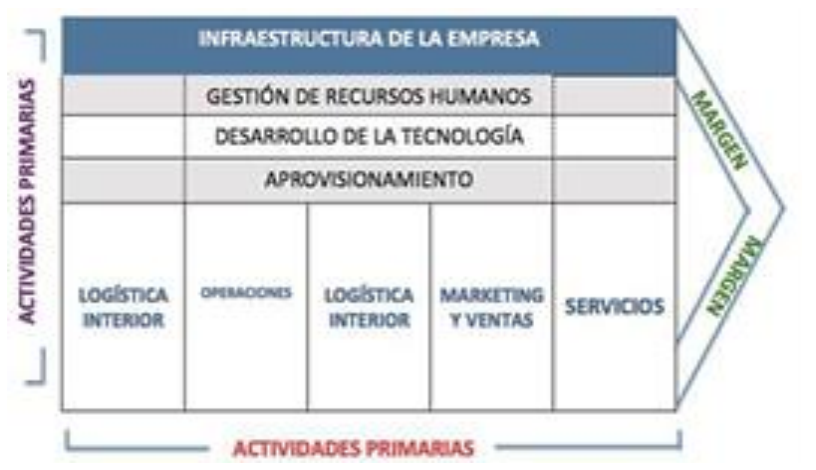

Figure 1

Source Value Chain: Michael Porter 
In Michel Porter's scheme within the Value Chain, three fundamental elements for the growth and permanence of SMEs are proposed:

1. In the primary activities are Marketing and Sales and Services.

2. Among the support activities, is the Development of Technology.

3. Another important aspect mentioned by the same Author, is to establish a Competitive Strategy, the company must initially define its competitive advantage, understanding this, how the value that a company manages to create for its customers (Porter, 2008). The advantage will allow the company to differentiate itself from its competition and be more attractive to its customers.

Taking into account the Technology Development of the value chain, Porter (2008) also points out that this is a great equalizer, since it can deteriorate the competitive advantage even of consolidated firms and push others to the forefront. He also points out that technology is in every valuable activity and technological change affects competition.

To permeate this philosophy in SMEs, it is necessary to note the importance of the incorporation of technology to potentiate its value chain. For example; for marketing and sales issues, they must have a website developed (initially) on a free platform, which allows them to publicize their products and / or services; This will allow them to enter the digital markets and be accessible to potential customers of the network. You can start with a website and then grow, as far as possible to your own application. Within the free platforms existing in the market, 4 of the most used are recommended with respect to a universe of 50 options:

1. Wix: "With Wix, you have the freedom to create a free web page that looks exactly like you dreamed it, no matter how much experience you have."

2. Weebly: "Professional e-commerce tools for entrepreneurs, all in one place"

3. Jimdo: "With Jimdo, take advantage of the power of artificial intelligence to offer you a fully customized web page adapted to your needs."
4. Word Press: "Word Press is a content management system or CMS (Content Management System, software tool to create, manage and manage a website), focused on the creation of any type of web page."

A website would allow SMEs to offer their products and services in the digital market, where digital sellers and buyers now converge. It is the necessary and mandatory tool today. Another important aspect mentioned in the Value Chain is marketing and sales. Therefore, to potentiate their advertising, generate possible sales and subsequently specify them, SMEs must enter the world of social networks; for which they must establish precisely the objectives they wish to achieve with them. There is a large number of social networks that can be used in an organic (free) way to increase customers, sales, image, etc. The following figure shows the possible social networks that should be used according to the objective to be achieved.

As you can see one of the most repetitive and far-reaching tools is Facebook, so it is the social network with the largest number of users. According to "El Economista" (2017) in June of that year, it reached 2,000 million active users. There are also more than 1,000 million people who use "groups" and more than 800 million who like something on Facebook every day.

It is worth mentioning that social networks must be used discreetly and according to the objective you wish to achieve, for this the main ones are mentioned. SMEs should consider their target (market profile) and use the social network that suits them.

Also in the same value chain parameter, if you want to grow your market through sales; Another proposal is to venture into the use of Marketplaces, which are platforms called "Digital Supermarkets" that offer products and / or services over the Internet. It is a website that allows sellers and buyers to interact to make a commercial transaction. According to Forrester Research data, they indicate that the marketplace trend is rising globally. In 2016, $50 \%$ of total eCommerce sales in the globe were through this model, which in 2017 increased to $56 \%$. 
"In Mexico, electronic commerce is a trend that nobody should ignore." (Andrés Piedragil 2014, p.28), in fact, for entrepreneurs, micro, small and medium enterprises (MISMEs). This modality, even with the barriers that still stop its full development, is an alternative that predicts pleasant surprises.

Amazon, eBay and Alibaba (TMall) are the three names that monopolize the marketplace globally, while in Mexico, Mercado Libre occupies an important place in this sector. These companies have grown exponentially in recent years, due to the success that e-Commerce is having in our country.

SMEs in our country have a great advantage in these types of markets. One of the main reasons why the Marketplace can help them is that only $100 \%$ of these types of companies have an online presence, according to Kubo Digital data.

One of the most recent competitors, which has also taken advantage of its impact as a social network, is Facebook, who at the end of 2016 saw its own marketplace born, offering its users one more option to not take off from its application, finding a way to offer articles of use; being an important niche for those who want to use this platform, in order to position items or services of their brand or company.

SMEs have in the different Marketplaces platforms, an important opportunity to offer and position their products. By joining these markets, which physically it would be very difficult to reach, they have the opportunity to grow and stay in the market.

Maybe the word could scare SMEs, but Facebook, one of the most popular social networks currently, has the Marketplace option as already mentioned and can be used by individuals and corporations that sell any type of product or service. Facebook allows SMEs to participate in their Marketplace and thus increase their sales possibility, which is the ultimate goal of any company. The last aspect that we will deal with regarding the Value Chain is the Service. As mentioned earlier, the current user or customer has become more demanding. That is why companies have incorporated into their processes some type of Customer Relationship Manager, CRM (Customer Relationship Management).
A CRM is a solution to customer relationships. They are normally oriented to three basic areas: commercial management, marketing and after-sales or customer service. There are many CRM options, there are even some that are free for a limited number of users. This type of software would allow SMEs to use the tool to streamline the customer service process and maintain a constant relationship with it, to make it a loyal customer. The following figures show some tools that can support SMEs in improving customer service.

\section{Conclusions}

As a result of the investigation it can be concluded that $99 \%$ of companies are SMEs, that 9 out of 10 tend to disappear from the market in the first 5 years of life. So it is considered that they have a very short life in it, and it is necessary that they develop marketing strategies that allow them to stay and grow in the market where they compete. It is also important that they develop a competitive advantage, which they can obtain if they incorporate new technologies and new digital marketing practices into their processes with the use of the WEB. The results of the investigation showed that $32 \%$ of these companies already have a WEB page and 76\% use social networks and it is Facebook that they use most, which has helped them grow the business, increase their sales and reach to more customers, not only in Mexico, but also in other countries. The use of the WEB and social networks in SMEs represents an advantage for incorporating the aforementioned digital marketing strategies. This project presents the proposal of Michel Porter that emphasizes the obtaining of the value chain with the application of marketing, sales and service strategies, in addition to the use of new technologies. It is suggested that companies create their website through free applications, use the networks according to their profiles and sales and marketing objectives, but in addition the use of the Marketplace is recommended and in a matter of customer service it is also suggested to incorporate Customer Management Systems (Consumer Relationship Management) that will allow them to collect information about customer interactions, which will help them get to know it better and in turn improve the offer and sale, customer loyalty and perform better segmentation. 
In the case of social networks, you must establish continuous communication with the client, for this you must incorporate applications that allow you to be in permanent contact with the client, as well as give accurate and timely responses, this proposal will benefit you because in addition to having your market physical, they can get customers in the digital market, which opens the possibility of expanding their field of action.

\section{References}

/Facebook-alcanza-los-2000-millones- deusuarios-20170627-0013.html (accessed octubre $28,2018)$.

2000-millones-de-usuarios$20170627-$ 0013.html (accessed octubre 28, 2018).

Cisneros E.D., (2017), E-commerce, Perú, Editorial MACRO Competitiva. México, CECSA

Economista. El Economista. junio 27,2017.https://www.eleconomista.com. $\mathrm{mx} /$ tecnologia/Facebook-alcanza-los- $\quad 2000-$ millones-de-usuarios-20170627- 0013.html (accessed octubre 28, 2018).

Goodstein, L.,(1998), Planeación Estratégica Aplicada,México, Mc. Graw Hill

Holly B,. (2006), Mercadotecnia en línea para SMEs, México, Grupo Patria Cultural

https://es.jimdo.com/

https://es.wix.com/

https://es.wordpress.com

https://noticias.universia.com.ar/practi casempleo/noticia/2016/07/07/1141525/50-

plataformas-crear-propio-sitio-web.html

https://www.weebly.com/mx

INEGI. Encuesta Nacional sobre Productividad y Competitividad de las Micros, Pequeñas y Medianas Empresas.

Informe, INEGI, Mexico: Sitio web, 2015.
La Jornada, "La corta vida de las SMEs." La Jornada. La Jornada. Mexico, Ciduad de Mexico, 2017.

Las SMEs en México aceleran su crecimiento con Facebook, extraído de http://pcworld.com.mx/las-SMEs-en-mexicoaceleran-su-crecimiento-con-facebook/, febrero 22 de 2018.

Mauberth, I. (2014, Noviembre 15), Entrepreneur, Abre tu tienda en línea y multiplica tus ventas con internet.

Navárez J,. (2014), E-commerce, México, Editorial Digital UNID

Porter, M., (2000), Estrategia

Porter, M., (2008), Ventaja competitiva, México, Editorial Patria

Steiner, G., (2009) Planeación Estratégica, México, Grupo Editorial Patria 